\title{
FACTORS CAUSING SEVERE DEAFNESS IN CHILDHOOD.
}

\section{by}

\author{
W. Hatchuel, M.B. B.Ch., (Rand), M.R.C.P.E., D.C.H.
}

In order to diagnose deafness, it is as well to bear in mind its causes. It is of interest therefore, to analyse the records at the St. Vincent's School for the Deaf, in Johannesburg, and to enumerate the causes of deafness as recorded there.

There are 221 children attending St. Vincent's School for the Deaf. Twelve of these children have been termed "aphasic" and are excluded from this analysis. The remaining 209, are children who have been referred to the school as being severely deaf and who require education in a school for the deaf.

m The factors causing deafness have been tabulated from the diagnoses recorded by doctors and other persons referring the children to the school. The analysis represents only an overall guide to the causes of severe deafness in children of school going age.

\section{FACTORS IN THE CAUSATION OF DEAFNESS}

\section{HEREDITARY CAUSES.}

2 families with 3 affected siblings:

17 families with 2 affected siblings:

10 families with 1 affected child, and other affected close relatives

Waardenburg's Syndrome Association with Ectodermal dysplasia Congenital absebce of auditory canals Associated with cleft palate

\section{INFECTION}

Inflammatory conditions affecting middle and inner ear etc.

\section{Encephalitis \\ Measles \\ Gastro Enteritis \\ Pneumonia}

Meningitis $\begin{array}{lr}\text { T. B. Meningitis } & 3 \\ \text { Meningococcal } & 1 \\ \text { Type not recorded } & 15\end{array}$

Rubella in Pregnancy

III DRUGS

Kantrex

* Streptomycin

Quinine

IV PERINATAL CAUSES

“"Spastic Paralysis"

Kernicterus

Birth Injury

Prematurity

V TRAUMA

VI MISCELLANEOUS

Mother in concentration camp during pregnance

Progressive deafness of unknown aetiology

\section{CONVENITAL SPORADIC DEAFNESS 95}

\footnotetext{
* Two cases of "Streptomycin toxicity" also included under T.B. Meningitis.
}

HEREDITY plays a prominent role in the causation of deafness, and in fact, accounted for more than a quarter of the cases. This is strikingly shown by the presence of 50 children in the school all of whom have a background history of family deafness; two families each have 3 children attending the school, another 17 families 
are children from families where either a parent or a close relative is affected.

There are certain well described hereditary syndromes in which deafness may appear as a feature. Embryologically the cochleae and ossicles form part of the 'first arch', and originate from the neural crest of the ectodermal tissues.

In 1958, McKenzie grouped a number of conditions, which could result from abnormal development of the stapedial artery during intra-uterine development. These conditions are transmitted genetically as a dominant gene with variable penetrance and they have as a common feature the possibility that deafness may exist. Under the term 'First Arch Syndrome', McKenzie included such conditions as :-

\section{The Treacher-Collins Syndrome}

1. The Treacher-Collins Syndrome (mandibulofacial dysostosis).

2. Pierre Robin Syndrome (hypoplasia fo the mandible with glossoptosis)

3. Mandibular dysostosis.

4. Deformities of the external and middle ear.

5. Congenital deaf-mutism.

6. Hypertelorism.

7. Cleft lip and cleft palate.

8. Waardenburg's syndrome.

Examples of these varied conditions are to be found among children attending this school.

The Waardenburg Syndrome. One child shows evidence of the condition. In its fully-developed form it is characterised by a grey forelock of hair, a white patch of vitiligo (depigmentation) on the forehead, eyes of two different colours (heterochromia of the irides) wide epicanthic folds and deafness. Only one or other of these features may appear in individual members of an affected family (i.e. the condition may occur genetically with incomplete penetrance of the affected gene). In the one affected child attending the school, there is heterochromia of the irides and deafness.

The association of deafness with various forms of ectodermal dysplasia is also well documented in the literature. At St. Vincent's, one child has congenital absence of the auditory canals. Another : has a sibling born with complete absence of hair, and a third has multiple congenital anomalies which include, among them, deafness, cataracts, and under-developed thumbs.

There are four children with cleft palates. Surveys among children with cleft palates show an incidence of deafness amounting to up to $20 \%$. This may result from a number of causes. In some, the deafness and cleft-palate are different features of the same inherent genetic defect (e.g. 'The first arch syndrome'). In others, it follows an increased tendency towards middle-ear infection, occurting as a result of the defective swallowing mechanism and short Eustacian tube which may accompany the condition.

Thus fifty-eight children attending the school acquired their deafness as a result of hereditary factors. This accounts for slightly more than a quarter of the cases. It would therefore be wise to study the family history, whenever cases of congenital deafness occur. Genetic counselling prior to marriage could become a potent force in the prevention of the condition. In all certainty, no person with a family history of hereditary deafness should be encouraged to marry into another similarly affected family.

INFECTIONS. Infections are a major factor in the aetiology of deafness. Firstly, there are the acute inflammatory conditions affecting the middle-ear and spreading to the mastoids and inner-ear ( 7 cases). These conditions are eminently treatable during their early phase and should rarely progress to deafness in this era of antibiotics and surgery. Such calamities do occur however. The very nature of their preventibility makes it im erative that every ear infection either acute or chronic - be treated vigorously. Any deterioration in the hearing patterns as shown by an audiogram, should result in medical reassessment of the child by the doctor; because early treatment, whether by antibiotics or by surgery, may be an important factor in the conservation of maximum hearing. Discharging ears must never be accepted as 'natural' and always require attention.

The second group deserving attention are viral infections. These may affect the brain and cochlear apparatus. Encephalitis (6 cases) may leave in its wake a terrible trail of brain damage and cochlear degeneration. A child's inability to understand and to speak after a severe encephalitis may often be ascribed to brain injury, but may 
also be due to lesser or greater degrees of dysaudia. A number of common infectious diseases which are often considered harmless by lay persons, may be accompanied by similar neural damage. The damage caused by measles (1 case), gastro-enteritis (1 case) and pneumonia ( 1 case) are examples. The latter two (gastro-enteritis and pneumonia) may well have been local manifestations of general viral or bacterial infection affecting the cochlea or brain, -although vascular insufficiency may also play a part.

A third group of infections - the Meningitides (19 cases are playing an increasingly common

A third group of infections - the Meningitides (19 cases) are playing an increasingly common role. Lives formerly lost from meningitis, are now being saved. A few, however, must pay for the privilege of life by surrendering their hearing. The organisms causing the meningitis may either affect the eighth nerve or the cochlea and deafness may ensue.

Tuberculous meningitis ( 3 cases) deserves a word on its own. Streptomycin is the principal drug used in the treatment of tubercolosis. This drug may, however, cause a severe hearing loss when given in excessive doses. It is often difficult to know which factor has caused the deafness, i.e. the disease or the treatment. In the early days of modern anti-tuberculosis treatment, doses of streptomycin which today are considered excessive, were administered, and this was a significant factor causing deafness. Today, Streptomycin is given to thousands of patients suffering from pulmonary tuberculosis, without ill effect, so that it would appear to be the Tuberculosis Meningitis, itself, rather than the streptomycin which now causes the hearing defect. Earlier cases, however, probably suffered hearing damage as a result of excessive treatment.

A feature of meningitis which deserves mention is the suddenness with which deafness can supervene, and the still unaccountably long delays between the onset of the deafness, the diagnosis and subsequent treatment. Such delays in early infancy inevitably cause loss of speech or retardation of language development. Early therapy can do much to assist in the conservation of existing speech.

Infection may affect a child prenatally as well as postnatally. Thus Rubella during the first three months of pregnancy ( 5 cases) is now wellestablished as a cause of disordered teratogenesis. It may cause one, or a number of congenital abnormalities, including deafness, cataracts, microcephaly and congenital heart-lesions. No harm is done if the infection occurs after the sixteenth week of pregnancy. It is not, however, inevitable that rubella will cause deafness; and the incidence of deafness following infection of the mother during these critical weeks seems to vary from year to year. This variation is probably an expression of the virulence of the particular organism prevalent in any given epidemic. It is probable, too, that the critical time is not during the entire period of 16 weeks. It is confined to a much shorter period of intra-uterine development, for it has been shown that individual congenital defects can be produced experimentally by inflicting damage at definite critical periods ofgrowth.

The concept that the growing foetus is defended from all harm during intra-uterine existence is now obsolete. Infection may harm the embryo or foetus at any time during pregnancy. It is not feasible, therefore, that an apparently minor infection affecting the pregnant mother could result in damage to the developing foetal auditory apparatus, and be responsible for a number of the cases so often diagnosed as 'idiopathic'?

\section{DRUGS.}

The role of streptomycin has al ready been discussed. Other drugs are al so known to cause deafness: Five injections of Kanamycin given as treatment for boils at the age of six months resulted in deafness in one child. In another, deafness followed malaria, and it is surmised that this was probably the result of quinine therapy.

\section{CEREBRAL PALSY.}

Only five children attending the school are also suffering from Cerebral Palsy. These five probably do not represent the total incidence of cerebral palsy as a cause of deafness, since a number of cerebral palsied deaf children are being treated in Johannesburg, at the Forest Town School for Cerebral Palsied Children. This group of children has been reviewed recently. Among the five cerebral palsied children attending St. Vincent's three have been diagnosed as spastic, and two are reported as having followed Kernicterus. It is apparent from the survey at: Forest Town that Kernicterus (bile staining the basal 
ganglia at birth, occurring in excessively jaundiced babies) is the commonest caust of deafness among the Cerebral Palsied, particularly among the group of children who are athetoid. Anoxia at birth ( 2 cases) is another factor and is also probably the cause in a number of children who are both spastic and deaf.

PREMATURITY is often cited as a cause of deafness. In this series 3 cases were recorded as being due to prematurity, although, without knowing the birth weights of the entire series, it would be unwise to give this statistical significance. In a series studied recently in Newcastle however, prematurity was not a significant

however, prematurity was not a significant factor nor was it in Wolman's series. It is probable

nor was it in Wolman's series. It is probable that many cases previously attributed to prematurity alone were actually cases of kemicterus of prematurity, followed by deafness, and that others were due to birth injury and anoxia associated wi th prematurity. One hopes that here too, preventative and therapeutic measures will eventually be effective.

Two children in the school suffer from epilepsy (i.e. about $1 \%$ ). This is the average incidence of epilepsy for any population, so that significance cannot be attributed to this association. It is, however, interesting to speculate whether the factor causing the epilepsy - be it hereditary or acquired - also caused the deafness.

TRAUMA was the probable cause in two cases.

The largest group still consists of children in whom no cause is apparent. These cases are referred to as 'CONGENITAL SPORADIC DEAFNESS' or 'Idiopathic Deafness'. When diagnostic methods improve, and as research reveals hitherto unknown reason's for deafness, this group will diminish proportionately. It is probable that out of these 92 children, there are some with recessive genes for deafness, where family histories are not sufficiently, well known to reveal other cases of deafness in the family. Other cases may well be due to kenicterus, the diagnosis having been missed at the time of damage - since the conditions was less well known a number of years ago.

One wonders how many cases of 'idiopathic' congenital deafness are due to intra-uterine drug toxicity when ototoxic drugs have been administered during pregnancy. The recent thalidomide disaster (where it was shown that thalidomide administered to pregnant mothers caused limb and other defects), and a parallel example in the known relationship between rubella and deafness, make it very likely that a casual relationship between deafness and other drugs that have been administered to pregnant mother, will eventually

administered to pregnant mothers, will eventually be found to exist.

\section{WHAT DO WE LEARN FROM THIS SURVEY?}

We learn of children whose deafness arose from preventible conditions, and we learn that deaf-ness is often present from birth. Increasing awareness of the causes of deafness should assist in preventing many cases. A few well-chosen questions can often identify a child who has been subject to the known factors causing deafness (i.e. to identify the children as having been 'at risk').

The fact that deafness, when present in childhood, usually dates from birth, should make us watchful for its presence from earliest infancy. Wherever and whenever possible, the condition should be diagnosed before the age of two years. In this way treatment by amplification with a hearing aid and audiotherapy may be started at an early age.

\section{SUMMARY.}

Records at the St. Vincent's School for the Deaf in Johannesburg were analysed, and the causes of deafness were enumerated.

209 Children were included in the analysis. The remaining 12 children have been termed 'aphasic' and were therefore excluded from the study.

The following factors as causes of deafness were discussed: Hereditary causes, Infection, Drugs, Perinatal Causes. Trauma, Miscellaneous and Congenital Sporadic Deafness.

This analysis represents an overall guide to the causes of severe deafness in children of school-going age. 
OPSOMMING.

Verslae van die St. Vincent's Skool vir Dowes in Johannesburg is ontleed om die oorsake van doofheid vas te stel.

209 Kinders is in die studie ingesluit. Die orige 12 kinders, wat as 'asfasies' bestempel is, is uitgesluit.
Die volgende faktore is as oorsake van doofheid bespreek: Oorerflike oorsake Infeksie, Verdowingsmiddels, Trouma, Diverse en Aangebore sporadiese doofheid.

Die ontleding kan beskou word as 'n algemene gids tot die oorsake van hoegraadse doofheid by skoolgaan de kinders.

\section{REFERENCES}

1. McKenzie J. (1958) The first arch syndrome. Arch. Dis. Childh. 33 477-86.

2. DiGeorge A.M., Olmstead R.W., Harley R.D. (1960). 'Waardenburg's Syndrome'. J. Pediat 57. 649-699.

3. Robinson G.C., Miller J.R., \& Bensman J.R. (1962). 'Ectodermal Dysplasia with sensori-neural Deafness and other Anomalies'. Paediatrics 30. 797.

4. Swan C., Tostevin A.L., Moore B., Mayo H., \& Batham Black G.H. (1943). 'Congenital defects in infants following infectious diseases during pregnancy'.

Med. J. Aust. (ii) 201.

5. Liggins G.C., Phillips L. I. (1963) 'Rubella Embryopathy'. Brit. Med. J. (i) 711.

6. Clayton Jones E. (1947) 'Rubella as a cause of congenital deafness in England'. Lancet $252156-61$.

7. Hatchuel W. (1962). 'The importance of performing adequate hearing tests in children with Cerebral Palsy. S.A. Med. J. 36. 13. 237.

8. Hatchuel W. \& Jacobs R. (1963) 'Hearing loss in Cerebral Palsied Children'. Paper read to the Paediatric Section of the 44 th Congress of the S. A. Medical Association. In publication.

9. Barton M.E., Court A.D. \& Walker W. (1962). Causes of severe deafness in School Children in Northumberland \& Durham'. Brit. Med. J. (i) 351.

10. Wolman B., (1963) 'Deafness in Children'. Arch. Dis. Childh. 38. 375.

11. Whetnall E. (1956) 'Discussion on the Management of deafness in young children'. Proc. R. Soc. Med. 49.455. 